胸腔鏡補助下に切除した横隔膜気管支原性囊胞の 1 例 自治医科大学附属大宮医療センター外科

岡田晋一郎石田博徳山田典子小西文 雄

症例は 40 墄，女性. 人間ドックの腹部超音波検查で右副腎腫瑒を疑われ，腹部 CT 検 查では右胸舼内に発生した径 $35 \times 25 \mathrm{~mm}$ 大の充実性腫湟を指摘され, 当院呼吸器外科を 紹介された，腫瘍マーカーは正常だった。手術は胸腔鏡補助下に施行し，術中所見は右 横隔膜内に弾性軟の $3 \mathrm{~cm}$ の腫瘤を認めた。主に超音波凝固切開装置 (LCS) を用いて壁 側胸膜と横隔膜筋線維を切開剝離し, 腫瘤を摘出した。術中に被膜の損傷があり, 内部 からクリーム状の混濁した内容液が流出し，輬胞であると判明した，病理組織所見では 黄胞壁は気管支上皮で覆われ，軟骨や気管支腺も含むため，気管支原性咅胞と診断され た. 気管支原性豪胞は主に綐隔や肺内に発生する先天性烡胞で, 横隔膜に発生すること は稀で, 本邦では 9 例の報告をみるのみである. 今回われわれは, 腹部超音波スクリー ニング検查で発見し，胸腔鏡補助下に切除した右横隔膜気管支原性衰胞を経験したので 文献的考察を含め報告する.

索引用語：気管支原性豪胞，横隔膜腫瘍，胸腔鏡手術

\section{緒言}

横隔膜に発生する気管支原性毫胞は稀である。今回 われわれは右横隔膜上に発生した気管支原性鞬胞を胸 腔鏡補助下に切除した 1 症例を経験したので，文献的 考察を加え報告する。

症例

患者：40歳, 女性.

主訴：人間ドックで腹部エコー上の腫瘤像を指摘.

既往歴：更年期障害.

家族歴：特記事項なし。

喫煙歴：なし。

アレルギー歴：造影 CT 検査後に軽度気分不快あ $\eta$.

現病歴：2003年 4 月に人間ドックを行った際に，腹 部超音波検查で右腎頭側に $3.7 \mathrm{~cm}$ 大の腫瘤を指摘さ れた。 2 日後当院内科外来受診し，腹部超音波検査， 胸腹部造影 CT 検查で右胸腔内腫瘤と診断され，呼吸 器外科に紹介された。前回造影 CT 施行後に気分不快 が出現したため, 呼吸器外科紹介後, 前回より狭いス

2005年11月 8 日受付 2006 年 3 月 10 日採用 〈所属施設住所〉

テ330-8503 さいたま市大宮区天沼町 1-847
ライス幅で撮影した HRCTを造影滆は用いずに施行 した. 当科紹介より約 1 力月後に腫瘤切除目的に入院 した。

入院時現症：身長 $160 \mathrm{~cm}$, 体重 $51 \mathrm{~kg}, \mathrm{BMI} 19.9 \mathrm{~kg} /$ $\mathrm{m}^{2}$, 呼吸音心音ともに正常であった。呼吸困難, 咳嗽 なく, 腹部, 胸部体表に異常なく, 特に自覚症状もみ られなかった。

血液生化学検査所見：血算, 生化学, 電解質, 凝固 系に異常なく, 腫瘍マーカーはCEA $0.7 \mathrm{ng} / \mathrm{ml}, \mathrm{CA} 19$ $-97.8 \mathrm{U} / \mathrm{ml}$, シフラ (CK19フラグメント) $1.2 \mathrm{ng} / \mathrm{ml}$, NSE (RIA) $4.9 \mathrm{ng} / \mathrm{ml}$, シアリル Lue-i (SLX) $25 \mathrm{U} /$ $\mathrm{ml}$, SCC $0.6 \mathrm{ng} / \mathrm{ml}$, Pro GRP $23.5 \mathrm{pg} / \mathrm{ml}$ といずれも 正常値だった。

血液ガス所見 : $\mathrm{pH} 7.391, \mathrm{PCO}_{2} 41.9 \mathrm{mmHg}, \mathrm{PO}_{2}$ $110.4 \mathrm{mmHg}, \mathrm{HCO}_{3} 24.9 \mathrm{mmol} / \mathrm{l}, \mathrm{BE}-0.1 \mathrm{mmol} / \mathrm{l}$, $\mathrm{SatO}_{2} 98.7 \%$ と正常だった.

呼吸機能検查 : VC 3.041, 107\%, FEV 1.02 .651 , $82.8 \%$ と正常だった。

胸部単純 X 線写真：立位正面吸気像で右第12肋間 に $3 \mathrm{~cm}$ 大の半円状陰影が認められ, 呼気像で第11肋 間に移動がみられた(図 1). 側面像では肝実質陰影に 重なり，横隔膜下に円形陰影は認められなかった。

胸腹部 $\mathrm{CT}$ 検査 : 右横隔膜上に $3.5 \times 2.5 \mathrm{~cm}$ 大の表 


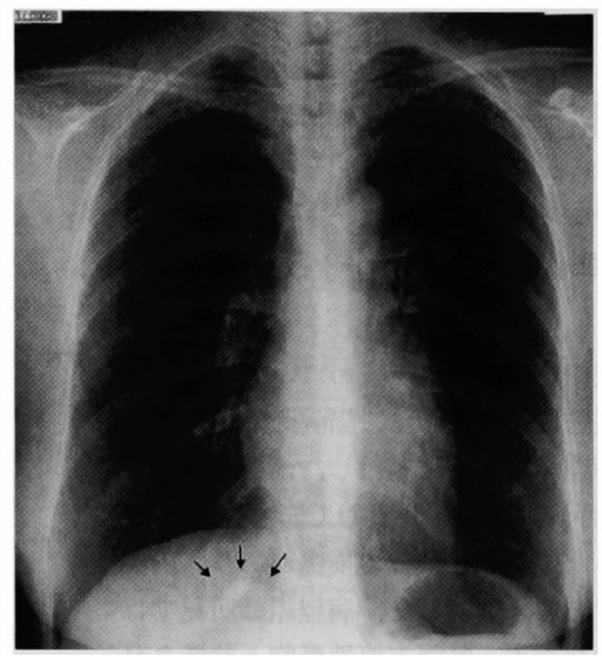

図 1 胸部単純 $X$ 線写真検查: 立位正面吸気 像で右第12肋間に $3 \mathrm{~cm}$ 大の半円状陰影を認 める。

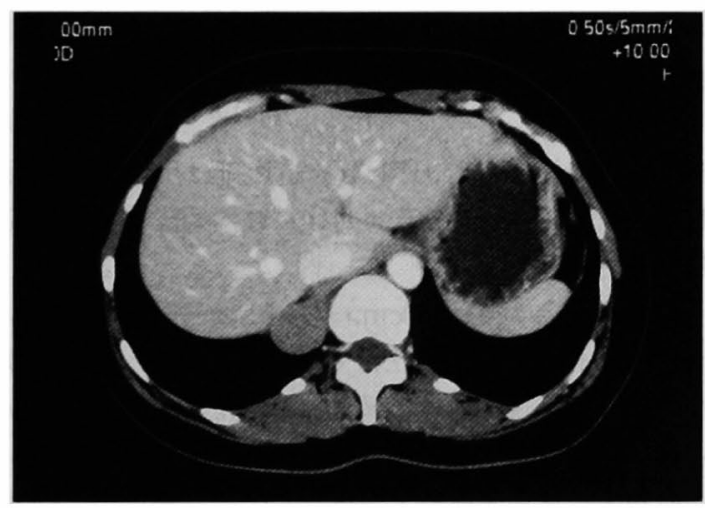

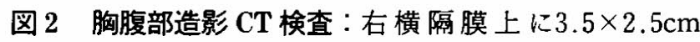
大の表面平滑で球形の内部均一な腫瘤を認める。

面平滑な球形の腫瘤で，内部構造は均一であった，造 影剤による増強はなく, 単純 $\mathrm{CT}$, 造影 $\mathrm{CT}$ とも腫瘤内 部の CT 值は90〜110で変化はみられなかった(図 2 ).

術前診断は(1)胸膜に発生した solitary fibrous tumor, (2) neurogenic tumor, (3) Inflammatory tumor を鑑別診断に挙げた。

手術所見：左側臥位で第 7 肋間と第 9 助間から胸腔 用ポートを挿入した，背側横隔膜上に $3 \mathrm{~cm}$ 大のなだ らかな隆起病変がみられ, 腫瘤は横隔膜から発生して いるようであったため, 第11肋間後方に $8 \mathrm{~cm}$ の小開 胸を加えた.腫瘤の被膜を露出するように切開すると, 腫瘤は横隔膜の筋層から発生していた，剩離操作の際

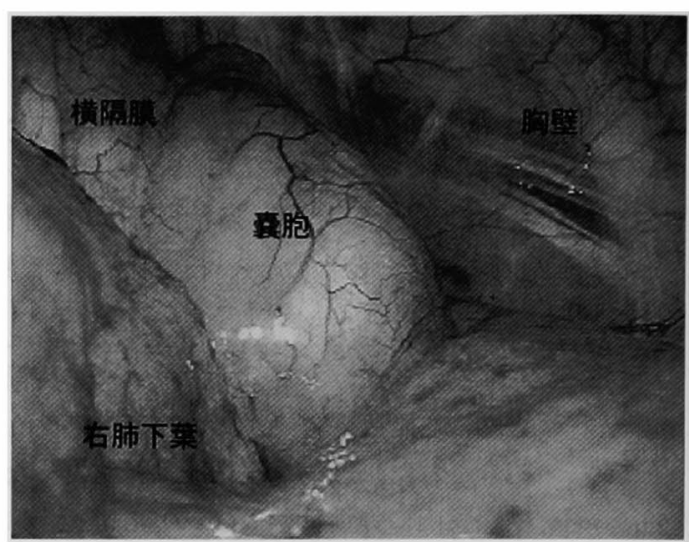

图 3 術中写真 : 右背側横隔膜上に $3 \mathrm{~cm}$ 大の表面平滑 な腫瘤を認める。横隔膜, 胸壁, 右肺下葉との位置関 係は図内に示す。

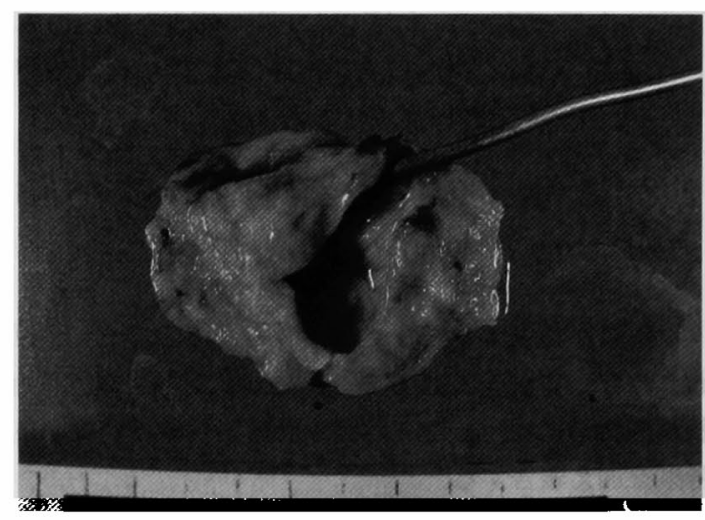

図 4 切除標本所見 : 単房性薪胞で, 灰白色の内容液を 含み, 内腔に隆起病変はみら机ない。

に被膜を損傷し, 内部から灰白色の液体が流出した. 腫瘤は被膜ごと核出し, 境界の切離操作には主に超音 波切開凝固装置 (LCS) を用いた. 横隔膜の欠損部は 2-0 Dexon 糸で縫合修復した. 摘出された標本は単房 性の囊胞で, 内腔に隆起病変はみられなかった。ここ に術中写真を示す (図 3 ).

病理組織所見: $3.5 \mathrm{~cm}$ 大の穓胞内面は多列線毛上 皮で覆われ, 壁に軟骨, 気管支腺, 平滑筋組織を認め た. 肺胞組織はみられなかった. Bronchogenic cyst in diaphragma と診断された(図 4,5：HE 染色法, 200 倍).

術後経過：創部痛は軽微で, 術後 3 日目に胸腔ドレ ーンを抜去し, その後著変なく, 術後13日目に退院し た. 


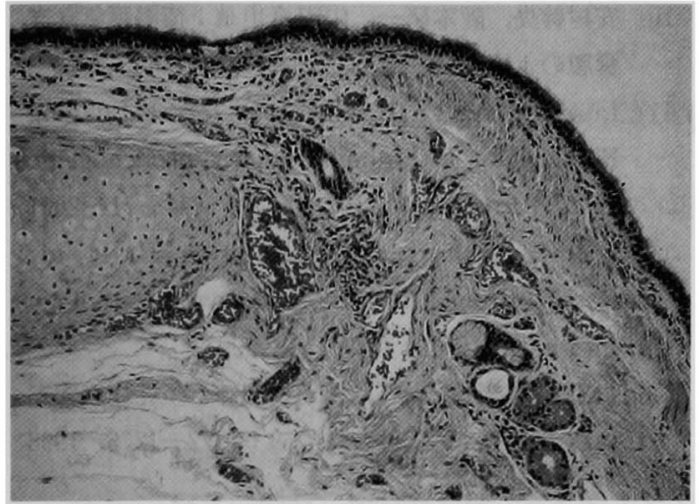

図 5 病理組織所見：多列線毛上皮で覆われ，壁に軟骨， 気管支腺, 平滑筋組織を認める (HE 染色法, 200倍)。

\section{考察}

気管支原性裹胞は，胎生期に前腸 (foregut) の腹側 肺芽から発生した気管気管支原基の異常発芽や迷入よ り発生すると考えられている1). 気管支原性襄胞の発 生部位はほとんどが肺内と綐隔であり, 横隔膜に発生 することは稀である ${ }^{2 / 3)}$. 横隔膜気管支原性鸾胞の本邦 報告例は, 内山らが報告(4)して以来, 本例を含め 17 例18 病変報告されている. 男性 9 例女性 8 例で, 年齢は 13〜74歳であった. 本例のように胸架側に生じた横隔 膜上気管支原性哓胞が13病変と多く, 横隔膜内に発育 した気管支原性衰胞も 1 病変認められた。また，横隔 膜下気管支原性壤胞は 4 病変であった。 1 例を除き単 発性で, 形態は多房性が 7 病変, 単房性が 9 病変, 詳 細不明なものが 2 病変 ${ }^{5}$ とのことで, 本症例は単発単 房性で最も頻度の高い型であった。

気管支襄胞が横隔膜や腹部に発生する機序として, 1 つは前腸から呼吸原基が発生する時期にはまだ横隔 膜が形成されていないため, 奇形として発生した気管 支豪胞が胸腹膜管を通って後腹膜腔に迷入したとする ものという説があり，もう1つには胸腔内組織が，腹 膜脱出のメカニスムとして teratomatous な変化によ って気管支亯胞様の組織に変化したと考えるものがあ る.このことは腹腔内だけでなく横隔膜内に発生する ものがみられることや横隔膜を介して胸腹腔にまたが って dumbbell 状に発生した症例があることから前者 の説が有力である ${ }^{677}$.

また, 発生部位は左右別で左側が16病変, 右側が本 症例を含めて 2 病変と少ない. 左側に多い理由として 川口らは, 右背側大動脈は胎生 6 週末に消失するので,
右側に迷入した肺芽は血流を受けにくいためと推察し ている ${ }^{819)}$. Budding は呼吸原基より分離した肺芽が食 道間膜に迷入し，食道の成長に伴い尾側へ移動すると している1).したがって，自験例のように右側に生じた 例は珍しいものと思われる。

気管支原性䘫胞の画像所見は, その内容物の蛋白含 量, カルシウム濃度などにより変化するとされる. CT では水と同等の CT 值（10-20）をとることが多いが, 時に 90 程度の CT 值をとり, 実質性腫煌と鑑別困難に なる ${ }^{1011)}$. 本例の CT 値は85〜100であり, 造影前後で 変化はみられなかった，また，自験例では測定しなか ったが, 異胞内容液の成分を測定し, amylase, CEA, CA125,CA19-9が異常高値を認めたという報告もみら れている ${ }^{12)}$. 自験例においてはCT 検查の所見から気 管支原性雃胞を鑑別診断に挙げるべきであったと考え た.自験例では施行しなかったが, MRI 検査では T1強 調像では水成分よりやや high intensity $に ， T 2$ 強調像 では著明な high intensityを呈するとされているた め, 自験例でもMRI 検查を施行していれば術前診断 に有用であったと思われた ${ }^{13)}$.

本症例においては，胸腔鏡を用い，まず腫瘍の局在 と発生部位を観察し，それに応じて適切な肋間小開胸 をおくことで低侵襲な手術が可能であった。

\section{結 語}

左側横隔膜上に発生した，稀な気管支原性粪胞の1 例を経験したので報告した.

\section{文献}

1) Buddington $W T$ : Intradiaphragma cyst. New Eng J Med 257:613-615, 1957

2）押切太郎, 矢野 諭, 高木良三他：横隔膜を合併 切除した横隔膜原発気管支原性衰胞の 1 例. 北海 道外科誌 $43: 43-46,2002$

3) Coselli MP, de Ipolyi P, Bloss RS, et al : Bronchogenic cysts above and below the diaphragm. Ann Thorac Surg 44:491-494, 1987

4）内山喬一,川上義和, 大崎 饒他：横隔膜に発生 した気管支蕧嗹の 1 例. 日胸臨 $31: 470-475$, 1972

5）浜口伸正, 大西一久, 開發展之他：横隔膜下, 横 隔膜左脚に発生した気管支原性謈胞の 1 切除例. 胸部外科 $55: 523-525,2002$

6）大橋龍一郎，原 浩平，松田英祐他：後腹膜腔に 発生した異所性気管支暴胞悪性化の 1 例. 日消外 会誌 $34: 36-40,2001$ 
7) Hoang $\mathrm{C}$, Aubriot $\mathrm{MH}$, Totobenazara JL, et al: Isolated retroperitoneal intradiaphragmatic bronchogenic cyst. Clin Exp path $47: 67$ $-70,1999$

8）川口信之, 種池 真, 川上光一他：横隔膜に発生 した気管支原性素胞の 1 例. 臨床 MRI 記念症例 集: 121-125, 1999

9) Dagenais F, Nassif E, Dery R, et al: Bronchogenic cyst of the right hemidiaphragm. Ann Thrac Surg 59 : 1235-1237, 1995
10）安村幹央, 阪本研一, 山田卓也他：横隔膜気管支 蒦腫の 1 切除例. 臨外 $57: 1141-1145,2002$

11) Liou $\mathrm{CH}$, Hsu $\mathrm{HH}$, Hsueh $\mathrm{CJ}$, et al : Imaging Findings of Intradiaphragmatic bronchogenic cyst. J Formos Med Assoc 100:712-714, 2001

12) Itoh $H$, Shitamura $T$, Kataoka $H$, et al : Retroperitoneal bronchogenic cyst. Pathology International $49: 152-155,1999$

13）大楽耕司, 西健太郎, 杉 和郎他: 多発性気管支 㟟胞の 1 例. 日臨外会誌 $59: 1272-1276,1998$

\title{
A CASE OF INTRADIAPHRAGMATIC BRONCHOGENIC CYST SUCCESSFULLY RESECTED BY VATS
}

\author{
Shinichiro OKADA, Hironori ISHIDA, Noriko YAMADA and Fumio KONISHI \\ Department of Surgery, Jichi Medical University, Omiya Medical Center
}

Bronchogenic cysts usually occur in the mediastinum and the lung. We present a rare case of bronchogenic cyst that originated from the diaphragm. A 40-year-old woman was admitted for a right adrenal gland tumor found during an ultrasonic examination in a general health screening. We pointed out that the tumor was in the right thoracic space on showing the chest computed tomography scan. A smooth round mass $35 \times 25 \mathrm{~mm}$ in diameter was demonstrated on the CT scan. The patient's serum tumor marker level was in the normal range. The tumor was removed by a thoracoscope-assisted operation upon observation in the right diaphragm muscle tissue. We used an ultrasonic incision device (LCS) to cut around the tumor, which contained a kind of cream. It was diagnosed as bronchogenic cyst by pathological examination, a rare case that had developed in the diaphragm. Only 9 cases have been reported in Japan to date. It is important that surgeons recognize that a bronchogenic cyst is one of the possible disease encountered upon finding an intra-diaphragm tumor. 